\title{
Analysis of Musculoskeletal Disorders (MSDs) of Pharmaceutical Workers
}

\author{
Ergonomics and Work Physiology Program \\ Medical Science Faculty, Udayana University \\ Denpasar, Bali \\ adesri77@gmail.com \\ Ergonomics and Work Physiology Program \\ Medical Science Faculty, Udayana University \\ Denpasar, Bali \\ Ergonomics and Work Physiology Program \\ Medical Science Faculty, Udayana University \\ Denpasar, Bali \\ Departement of Mechanical Engineering \\ Faculty of Engineering, Udayana University \\ Jimbaran, Bali
}

Ade Sri Mariawati ${ }^{1}$, I Putu Gede Adiatmika², Nyoman Adiputra ${ }^{3}$, I Wayan Surata ${ }^{4}$

\begin{abstract}
Pharmaceutical work activities have a high repetition level with a work attitude of standing for 8 hours potentially causing musculoskeletal complaints, which can occur despite the normal work posture. This study aims to determine musculoskeletal disorders (MSDs) and the level of MSDs based on what categories are felt, the level of complaints, the level of frequency, and the severity. The research design using the questionnaire Nordic Body Map. The study was conducted in 17 pharmacies on 54 pharmaceutical workers. The results obtained by MSDs complaints based on what categories of pain statements obtained (43.2\%), cramps (16.13\%), aches (53.5\%). The category of complaint level obtained statement rather sick $(55.9 \%)$, sick $(33.5 \%)$. The category of frequency level obtained by the statement that occurs 1 to 2 times per week (56.5\%), and every day $(10.6 \%)$. And the severity category states that the perceived complaint is still working $(49.06 \%)$ and uncomfortable $(47.1 \%)$.
\end{abstract}

Index Terms - Muscle Fatigue, MSDs, Nordic Body Map, Pharmacist Assistant

\section{INTRODUCTION}

Musculoskeletal complaints are complaints on the part of skeletal muscles that are felt by someone ranging from mild complaints to very sick. Risk factors for musculoskeletal disorders (MSDs) include excessive workload, frequency/repetition, exposure time, work posture, total mechanical load, quality of risk (high strength intensity, repetition, large exertion, muscle stretching, environmental and psychosocial conditions not good). Fatigue or damage to muscles can result in muscle cramps (spasm), muscle spasms, loss of balance, and sprains. Muscle fatigue can also cause severe pain and cause (loss of sensation loss sensation) in the body that is burdened.

Pharmaceutical workers work 8 hours a day. Activities of pharmaceutical workers are serving the purchase of prescription and non-prescription drugs (Over The Counter / OTC). The service is carried out with continuous and repetitive activities without active breaks due to the arrival of patients with very high frequency. High repetition rates have the potential to cause fatigue and musculoskeletal complaints. The prevention of Occupational Diseases mentions Musculoskeletal disorders (MSDs) representing $59 \%$ of the total disease records found in [1]. While based on the results of 2013 basic health research the prevalence of musculoskeletal diseases in Indonesia based on those diagnosed by health workers is $11.9 \%$ and based on diagnosis or symptoms that is $24.7 \%$ [2].

Conducted a study on the prevalence and causative factors of musculoskeletal disorders in the tire industry warehouse operator in one of the companies in Tangerang [3] using the Nordic Body Map questionnaire, where the results showed that the highest MSDs level occurred in the lower back, with the factors that influence the risk of MSDs are age, weight, last education and length of work for the lower back, knees, and ankles.

A study on the prevalence of work-related musculoskeletal disorders (WMSD) and ergonomic risk 
assessment among Bangladesh's readymade garment workers, where the results, among 186 female respondents, 46 reported lower back pain $(24.7 \%)$ and 44 neck pain $(23.7 \%)$. Among 46 male respondents, 10 reported neck pain $(21.7 \%)$ while 6 reported knee pain $(13 \%)$. To overcome musculoskeletal risk factors through ergonomic intervention in terms of workspace, sitting/standing posture, sitting and hand positions during the work cycle and rest are encouraged in the RMG sector [4].

\section{METHOD}

This research is a descriptive observational approach cross-sectional. The study population was all drug service workers in 17 pharmacies randomly located in Cilegon and Serang, Indonesia. The study was conducted on 54 pharmaceutical workers in the drug services department.

Data obtained through direct observation, interviews for filling the Nordic Body Map (NBM) questionnaire. NBM assessment includes 28 parts of skeletal muscle starting from the upper muscle, namely the neck to the lowest part, the leg muscles. In this study, the NMB used was broken down by category of the level of complaint, level of perceived, level of frequency and severity. For the level that is felt to have a category of 7 namely pain/pain (1), heat (2), cramps (3), numbness (4), swelling (5), stiffness (6), aches (6). The level of complaints consists of categories of very sick (1), not sick (2), somewhat sick (3), sick (4) and very sick (5). For the level of frequency, the categories consist of 1 to 2 times per year (1), 1 to 2 times per month (2), 1 to 2 times per week (3) and every day (4). The severity of the category consists of mild/uncomfortable (1), moderate but still working (2), severe and unable to work (3), very severe and having to take time off (4).

\section{RESULT}

Recapitulation of respondent data that presents an overview of pharmaceutical workers consisting of age, years of service, work position and complaints of musculoskeletal disorders is shown in Table 1.

TABLE I

\section{RECAPITULATION OF RESPONDENT DATA}

\begin{tabular}{lcc}
\hline Gender & Total & Percentage \\
\hline Female & 48 & $88,90 \%$ \\
\hline Male & 6 & $11,10 \%$ \\
\hline Age & Total & Percentage \\
\hline 17-19 years & 6 & 11,1 \\
\hline 20-34 years & 40 & 74,1 \\
\hline 35-50 years & 8 & 14,8 \\
\hline $\begin{array}{l}\text { Working } \\
\text { time }\end{array}$ & Total & Percentage \\
\hline$\leq 5$ years & 48 & $88,90 \%$ \\
\hline$>$ 5 years & 6 & $11,10 \%$ \\
\hline Total & 54 & $100 \%$ \\
\hline
\end{tabular}

Recapitulation of the respondent's characteristics includes exercise habits, exercise routines, types of exercise performed after work, whether there are complaints that are felt on the body, things are done when sick, doing a doctor's examination if experiencing complaints, time to feel pain are shown in Table 2.

TABLE II

RECAPITULATION OF THE CHARACTERISTICS OF RESPONDENTS (PHARMACY WORKERS)

\begin{tabular}{|c|c|c|c|c|}
\hline \multicolumn{2}{|l|}{ Statement } & Yes $(\%)$ & & No $(\%)$ \\
\hline \multicolumn{2}{|c|}{ Pharmaceutical workers exercise regularly } & 70,37 & & 29,63 \\
\hline \multicolumn{2}{|l|}{ Feeling achy in body parts } & 83,33 & & 16,67 \\
\hline \multicolumn{2}{|c|}{ Go to the doctor when you feel pain } & 85,19 & & 46,00 \\
\hline \multicolumn{2}{|c|}{ Carry out other activities after work } & 55,56 & & 44,44 \\
\hline \multicolumn{2}{|l|}{ The amount of exercise } & Total & & $\%$ \\
\hline & Not at all & 39 & & 72,22 \\
\hline & once & 8 & 14,81 & \\
\hline & twice & 5 & 9,26 & \\
\hline & Three times & 2 & 3,70 & \\
\hline \multirow[t]{4}{*}{ Type of Sports } & Do not exercise & 17 & & 31,5 \\
\hline & Aerobics & 1 & & 1,9 \\
\hline & Jogging & 30 & 55,6 & \\
\hline & etc & 6 & 11,1 & \\
\hline \multirow[t]{3}{*}{ Muscle pain } & Feeling sick / during work & 13 & & 24,1 \\
\hline & Feels sick after doing work & 30 & & 55,6 \\
\hline & Feels sick only at night & 10 & 18,5 & \\
\hline
\end{tabular}




\begin{tabular}{|c|c|c|c|c|}
\hline & Feeling sick at the end of the week & 1 & 1,9 & \\
\hline & Others & 0 & 0,0 & \\
\hline \multirow[t]{5}{*}{ Things done when sick } & Get enough rest & 15 & & 27,8 \\
\hline & Doing Massage & 12 & & 22,2 \\
\hline & Using external medicine & 20 & 37,0 & \\
\hline & Taking medication & 7 & 13,0 & \\
\hline & Others & 0 & 0,0 & \\
\hline \multirow[t]{3}{*}{ Type of activity } & Rest immediately & 16 & & 29,6 \\
\hline & Doing Homework & 30 & & 55,6 \\
\hline & Others & 8 & 14,8 & \\
\hline
\end{tabular}

The distribution of complaints about each body area with the 5 highest complaints based on the percentage of the number who felt the complaints are shown in Table 3.

TABLE III

\begin{tabular}{ccc}
\multicolumn{3}{c}{ COMPLAINT MSDS IN THE AREA OF THE BODY } \\
No & Complaint Area & Total Complaint $(\%)$ \\
\hline 1 & Calves \& legs & 100,00 \\
2 & Shoulder & 89,16 \\
3 & neck & 82,30 \\
4 & Waist \& Hips & 78,90 \\
5 & Knee & 65,16 \\
\hline
\end{tabular}

The MSDs category level includes perceived level, level of complaint, level of frequency and severity are shown in Table 4.

TABLE IV

LEVEL CATEGORY MSDS

\begin{tabular}{|c|c|c|c|c|c|}
\hline No & Leve of MSDs & Categori & Total & & $\%$ \\
\hline \multirow[t]{7}{*}{1.} & \multirow{7}{*}{$\begin{array}{l}\text { Level of } \\
\text { Perceived }\end{array}$} & Illness / pains & 67 & & 43,23 \\
\hline & & Hot & 9 & 5,81 & \\
\hline & & Clam & 25 & 16,13 & \\
\hline & & numb & 3 & 1,94 & \\
\hline & & Swollen & 4 & 2,58 & \\
\hline & & Stiff & 4 & 2,58 & \\
\hline & & aches & 83 & 53,55 & \\
\hline \multirow[t]{5}{*}{2.} & \multirow{5}{*}{$\begin{array}{l}\text { Level of } \\
\text { Complaint }\end{array}$} & Very not sick & 2 & & 1,2 \\
\hline & & Painless & 12 & 7,5 & \\
\hline & & A little sick & 90 & 55,9 & \\
\hline & & Sick & 54 & 33,5 & \\
\hline & & Very ill & 3 & 1,9 & \\
\hline \multirow[t]{4}{*}{3.} & \multirow{4}{*}{$\begin{array}{l}\text { Level of } \\
\text { Frequency }\end{array}$} & $1 \mathrm{~s} / \mathrm{d} 2$ times $/$ year & 8 & & 5,0 \\
\hline & & $1 \mathrm{~s} / \mathrm{d} 2$ times/month & 45 & 28,0 & \\
\hline & & $1 \mathrm{~s} / \mathrm{d} 2$ times / week & 91 & 56,5 & \\
\hline & & everyday & 17 & 10,6 & \\
\hline \multirow[t]{4}{*}{4} & \multirow[t]{4}{*}{ Level of Severity } & Light / uncomfortable & 76 & & 47,80 \\
\hline & & Medium but still working & 78 & 49,06 & \\
\hline & & Severe and can not work & 5 & 3,14 & \\
\hline & & Very severe and must be off & 0 & 0,00 & \\
\hline
\end{tabular}

\section{DISCUSSION}

Areas of pharmaceutical work services include drug services, cashier services, drug procurement, administration and receipt of goods. This study identifies the level of musculoskeletal disorder (MSDs) in the area of over-thecounter and prescription drugs. OTC drug services (OTC) begin with the arrival of consumers for consultation of drugs to be purchased, then given an alternative offer if needed, and get the drugs needed, which are then delivered the drug to the queue of service transactions for consumers 
to then take after making a payment. Prescription services are carried out by first checking the prescription, checking the availability of the drug requested by the prescription, submitting the price to be paid, preparing the prescribed drug, delivering information on the terms of use, conducting transactions and delivering the drug to the consumer.

\section{Characteristics of Respondents}

From the results of the study shown in table 1 that the composition of workers by age is the majority of workers aged 20 -34 years $(74.1 \%)$ is, while the age group $\geq 35$ years as much as $14.8 \%$. Based on research data all workers experience musculoskeletal complaints even though the majority age is under 35 years. This is because the level of repetition of work is high, in a long duration and takes place every day. states generally complaints of skeletal muscles begin to be felt at the age of 25-65 years with the first complaint felt at the age of 35 years and continues to increase with age [5].

The composition of drug service workers is based on the majority of women with a percentage of $88.89 \%$, while there are $11.11 \%$ of male workers. One of the factors influencing MSDs is gender with a higher prevalence of musculoskeletal pain for women than men [6], meanwhile [7] In this study, pharmaceutical workers are dominated by female sex, but MSDs are felt by all workers, so complaints arising are not solely due to gender, there are other things that affect.

\section{The description of the condition of workers who are the object of research}

Musculoskeletal complaints obtained from the filling of NBM to 54 respondents consisting of 48 women 6 men. An overview of workers' conditions can be seen in Table 2. The results of the NBM assessment on a nominal data scale were done using two answers namely Yes and No data obtained that in the past year $83.33 \%$ stated Yes they had complaints of pain in the skeletal muscles and $16.67 \%$ stated There were no complaints on skeletal muscles.

\section{Pain in muscles}

The results of the study showed that pain in the muscles occurred after doing work (55.6\%) and feeling pain during work $(24.1 \%)$ can be seen in Table 2. This shows that the way of working and working conditions as a cause of pain occurs, pain complaints are felt after work because pharmaceutical workers ignore what they feel because they have to do a good job so that the pain is only felt when they are at rest. Based on this it is necessary to improve working conditions.

\section{Musculoskeletal disorders}

The general description of complaints occurred in pharmaceutical workers in the medical services department was the calves and legs (100\%), shoulders (89.2\%), neck (82.35\%), knees $(65.2 \%)$, waist and hips $(78,9 \%)$ can be seen in Table 3. The level of complaints is not always the same even in the same type of work, this depends on the work system in the area and the ergonomic risks that may arise in the area and type of work. This is consistent with the research which states the causes of musculoskeletal complaints caused by many factors including workload, body position at work, frequency and duration research by [8] and in accordance with the results of research [9] research which states that the waist, hips, neck, shoulders and calves that have the biggest percentage of complaints in-hospital pharmaceutical installations.

\section{Knee, Calf, and Feet}

One of the risk factors for MSDs is working with high frequency/repetition. The process of walking back and forth and up and down the stairs during 8 hours of work without active breaks due to the placement of drugs that are above and below the reach of the hands affect the tension of the leg muscles and calves. The occurrence of MSDs in pharmaceutical workers with standing work attitudes is in accordance with the research that states there is a relationship between standing work and MSDs and the relationship between standing work postures with complaints of leg pain in workers' mechanical activity according [10].

\section{Shoulder and Neck}

The next biggest complaint is the shoulder, this happens because pharmaceutical workers in carrying out their work often take drugs (odd postures) that are far above and below the reach of the hand with high frequency. In addition, pharmaceutical workers often do prescription drug compounding which is done repeatedly during working hours without active breaks. This is consistent with [8] research which states that MSDs in pharmaceutical installations occur in the upper neck and lower neck.

\section{Waist and Hips}

Pharmaceutical work in the ministry requires a longstanding position of work with an improper attitude (tiptoe, standing on one leg). When standing the center of gravity moves to the spine so the waist feels body weight, if the lumbar and abdominal muscles are not strong then the burden is on the spine so that it will pull on the ligament and the muscles that cause pain. In addition to standing too long, workers were also found to be doing work with the wrong way of standing, which was done with one foot in an upright position with leg muscles tightened and the other leg slightly bent with leg muscles slightly relaxed. If done too long, it has the potential to harm the pelvis and spine and suffer back pain. The process of taking drugs with the drug position above and below the reach of the hand which causes the body posture is not ideal due to forced effort, excessive activity, and tense body posture.

\section{Perceived Levels}

The results of the study stated that complaints against the perceived level category stated felt the level of aches $(53.55 \%)$ and declared pain/pain (43.23\%), cramps $(16.13 \%)$, heat $(5.81 \%)$, swelling $(2.58 \%)$, stiffness $(2.58 \%)$ and numbness $(1.94 \%)$ can be seen in Table 4. From the results of the current study, the level of a category that was felt was dominated by aches and pains caused by muscle tension and excessive muscle use, resulting in the accumulation of lactic acid in the muscles. 


\section{Level of complaints, Frequency Level and Severity Level}

The following research results can be seen in Table 4 . From the results of the questionnaire obtained the level of complaints of respondents who stated rather sick (55.9\%), sick $(33.5 \%)$, this was felt by pharmaceutical workers every day $(10.6 \%)$ and who felt 1 to 2 times a week (56.5\%) with a moderate level of severity $(49.06 \%)$ which means that perceived complaints still allow workers to do their work, but as many as $3.14 \%$ of pharmaceutical workers cannot do work due to aches and pains suffered after working.

\section{CONCLUSION}

The level of general complaints of MSDs is most felt in the calves, neck, shoulders, knees, waist, and hips. The level of MSDs complaints by category:

a) The perceived level has ached (53.5\%), aches/pains $(43.2 \%)$

b) The level of complaints complained of was somewhat sick $(55.9 \%)$, sick $(33.5 \%)$

c) The level of frequency is 1 to 2 times per week $(56.5 \%)$, and every day $(10.6 \%)$

d) Severity is moderate and can still work $(49.06 \%)$, uncomfortable $(47.1 \%)$.

\section{REFERENCES}

[1] A. Luttmann, "Preventing Musculoskeletal Disorder In The Workplace," https://apps.who.int/iris/handle/10665/42651, 20. https://apps.who.int/iris/bitstream/handle/10665/42651/924159053X. pdf?sequence=1\&isAllowed=y (accessed Jun. 28, 2020).

[2] M. of H. Ministry of Health, "Basic_Health_Research_Riskesdas." Ministry of Health of Republic of Indonesian, Dec. 01, 2013.

[3] C. E. Revadi, C. S. Gunawan, and G. J. Rakasiwi, "Prevalensi Dan Faktor-Faktor Penyebab Musculoskeletal Disorders Pada Operator Gudang Industri Ban PT X Tangerang Indonesia,’ J. Ergon. Indones. Indones. J. Ergon., vol. 5, no. 1, p. 10, Jun. 2019, doi: 10.24843/JEI.2019.v05.i01.p02.

[4] M. D. Hossain et al., "Prevalence of work related musculoskeletal disorders (WMSDs) and ergonomic risk assessment among readymade garment workers of Bangladesh: A cross sectional study," PLOS ONE, vol. 13, no. 7, p. e0200122, Jul. 2018, doi: 10.1371/journal.pone.0200122.

[5] P. Tarwaka, "Dasar-Dasar Pengetahuan Ergonomi Dan Aplikasi di Tempat Kerja”. Surakarta: Harapan Press, 2011.

[6] H. H. Sultan Bedu, "Faktor Yang Berhubungan dengan Gannguan Muskuloskeletal Pada Cleaning Service di RSUP Dr.Wahidin Sudirohusodo Makasar," 2013, Accessed: Jun. 28, 2020. [Online]. Available: https://core.ac.uk/reader/25491576.

[7] H. A. H. Wijnhoven, "Prevalence of Musculoskeletal Disorders Is Systematically Higher in Women Than in Men," ResearchGate, Nov. 2006.

https://www.researchgate.net/publication/6805038_Prevalence_of_M usculoskeletal_Disorders_Is_Systematically_Higher_in_Women_Th an_in_Men (accessed Jun. 28, 2020).

[8] K. Istighfaniar and M. Mulyono, "Evaluasi Postur Kerja dan Keluhan Muskoloskeletal Pada Pekerja Instalasi Farmasi,” Indones. J. Occup. Saf. Health, vol. 5, no. 1, Art. no. 1, 2016, doi: 10.20473/ijosh.v5i1.2016.81-90.

[9] B. M. Nuryaningtyas and T. Martiana, "Analisis Tingkat Risiko Muskuloskeletal Disorders (MSDs) dengan The Rapid Upper Limbs Assessment (RULA) dan Karakteristik Individu Terhadap Keluhan MSDs," Indones. J. Occup. Saf. Health, vol. 3, no. 3, pp. 160-169, 2014.

[10] S. M. Anggrianti, B. Kurniawan, and B. Widjasena, "Hubungan Antara Postur Kerja Berdiri Dengan Keluhan Nyeri Kaki Pada
Pekerja Aktivitas Mekanik Section Welding di PT. X," J. Kesehat. Masy. E-J., vol. 5, no. 5, Art. no. 5, Oct. 2017. 